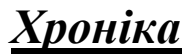

\title{
«Per scientium ad vitam»
}

Не буде перебільшенням сказати, що цього року однією з найпомітніших подій у наукових ботанічних колах всього світу було відзначення 200-річного ювілею всесвітньо відомого Нікітського ботанічного саду, який нині має офіційну назву «Нікітський ботанічний сад - Національний науковий центр Національної академії аграрних наук України» (далі Нікітський ботанічний сад або НБС-ННЦ).

Серед низки святкових заходів було проведення Міжнародної наукової конференції «Дендрологія, квітникарство та садово-паркове будівництво», присвяченої 200-річчю Нікітського ботанічного саду, м. Ялта, Україна, 5-8 червня 2012 р. До складу Оргкомітету конференції увійшли: голова - В.Н. Сжов, академік НААН, директор НБСННЦ, співголови - В.А. Дзоз, міністр освіти і науки, молоді та спорту АР Крим; Т.М. Черевченко, член-корр. НАН України, голова Ради ботанічних садів України; А.А. Іващенко, академік НААН, академік-секретар відділення рослинництва НААН, заступники голови - Г.С. Захаренко, заст. директора НБС-ННЦ; А.М. Ярош, заст. директора НБС-ННЦ; Ю.В. Плугатар, заст. директора НБС-ННЦ. До Наукового оргкомітету увійшли відомі вчені, керівники лабораторій та відділів НБС-ННЦ.

Конференція викликала великий інтерес, в ній взяли участь представники 17 країн Свропи та Азії. Найбільш представлені були наукові установи України та Росії.

Україну представляли вчені-ботаніки 3 багатьох ботанічних садів (БС): БС ім. О.В. Фоміна КНУ імені Тараса Шевченка; Національний БС ім. М.М.Гришка НАН України; Донецький БС НАН України; БС Дніпропетровського національного у-ту ім. О.Гончара; Кременецький ботанічний сад; БС Таврійського національного у-ту ім. В.I. Вернадського; Криворізький БС НАН України; Запорізький міський дитячий БС; БС Харківського національного у-ту; БС Чернівецького національного у-ту; низки університетів (Київський національний у-т імені Тараса Шевченка; Державний у-т управління та підприємництва, м. Київ; Херсонський державний у-т; Волинський національний у-т імені Лесі Українки, Національний у-т біоресурсів i природокористування, м. Київ; Південний філіал «Кримський агротехнологічний у-т» НУБіП; Національний лісотехнічний у-т (м. Львів); Запорізький національний університет; Ужгородський національний $\mathrm{y}$-т; Одеський національний $\mathrm{y}$-т ім. I.I. Мечникова; НУБіП України; Одеський національний медичний університет; Житомирський національний агроекологічний $\mathrm{y}$-т; Національний педуніверситет ім. М.П. Драгоманова; Білоцерківський національний аграрний університет та інших наукових установ (Біосферний заповідник «Асканія-Нова» ім.Ф.Е. Фальц-Фейна; Дендрологічний парк «Олександрія», м. Біла Церква; Національний дендропарк «Софіївка» НАН України; Український інститут експертизи сортів; Інститут садівництва НААН України; Інститут помології ім. Л.П. Симиренка НААН України; Інститут ефіроолійних і лікарських рослин; Дослідна станція лікарських рослин НААН України; Алупкінський палацово-парковий музей-заповідник; Селекційно-генетичний інститут - НЦ НС (м. Одеса); НІ лісового і паркового господарства НУБіП України; Карадазький природний заповідник НАН України.

Переважно були представлені матеріали господарів - вчених всіх відділів, відділень, дослідних станцій та дослідних господарств Нікітського ботанічного садуНаціонального наукового центру.

Росію представляли ботаніки Москви, Санкт-Петербурга, Скатеринбурга, Краснодара, Красноярська, Новосибірська, Сочі, Владивостока, Республіки Башкортостан, Воронежа, Бєлгорода, Волгограда, Омська, Апатитів, Саратова, Іркутська, Якутська, Геленджика, Кримська, Іжевська, П'ятигорська, Твері, Ростова-наДону та Желєзноводська. 
Казахстан представляли ботаніки Алмати, Мангишлака, Жезказгана, ІлеАлаутського національного парку. Були представники інших країн - Азербайджану, Бєларусі, Болгарії, Грузії, Киргизії, Латвії, Литви, Молдови, Німеччини, Польщі, Словаччини, Туреччини, Чеської Республіки і навіть Саудівської Аравії.

Урочисте відкриття конференції та виїзної сесії ботанічних садів і дендропарків України відбулося у великій конференц-залі Нікітського ботанічного саду. Численні делегації тепло вітали колектив Нікітського ботанічного саду, вручали для музею БС сувеніри та художні полотна переважно ботанічної тематики. Особливо відзначилася делегація Національного дендропарку «Софіївка» з Умані, яка під час привітаня з 200річним ювілеєм виконала урочисту пісню-гімн «Многая літа», виразивши побажання всіх учасників подальшого процвітання Нікітському ботанічному саду та великих успіхів його колективу.

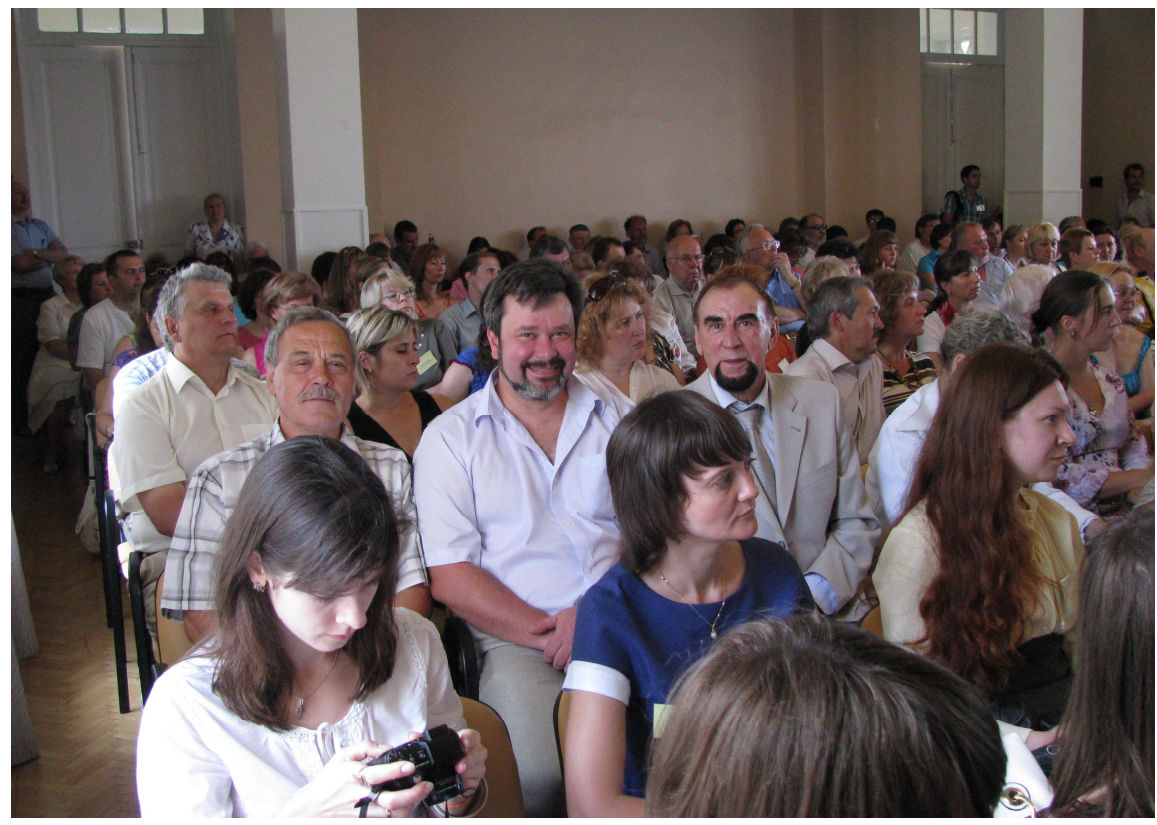

Рис. 1. На пленарному засіданні конференції у великій конференц-залі Нікітського ботанічного саду, 6 червня 2012 р. У 2-му ряду (зліва - направо): М.Ф. Бойко, О.Є. Ходосовцев (Херсонський університет), В.Д. Работягов (Нікітський ботанічний сад), за ними у 3-му ряду - С.Ф. Котов (Таврійський університет).

Fig. 1. At the plenary session of the conference in a large conference room of Nikitsky Botanical Garden, June 6, 2012 In the 2nd row (left - right): M.F. Boyko, A. Khodosovtsev (Kherson University), VD Rabotyagov (Nikitsky botanical garden) behind them in the 3rd row - S.F. Kotov (Tavrijsky University).

На пленарному засіданні (6 червня 2012 р.) були прочитані такі доповіді: Єжов В.М., Захаренко Г.С. - Про внесок Нікітського ботанічного саду в розвиток декоративного садівництва i багаторічного рослинництва на півдні України; Черевченко Т.М., Буюн Л.І., Ковальська Л.А. - Тропічні і субтропічні орхідні в НБС ім. М.М.Гришка НАН України; Драгавцева I.А. - Біоекологічне забезпечення продуктивності плодових культур півдня Росії на основі комп'ютерних карт адаптивного розміщення; Карпісонова Р.А. - Перспективність інтродукції багаторічників різних життєвих форм; Толкачова Н.В., Палій А.С. - Біохімічні дослідження в НБС-ННЦ. Історія, розвиток, перспективи.

6 і 7 червня 2012 р. відбувалися засідання секцій. Секція 1-1. Інтродукція, біоекологічне вивчення і селекція декоративних рослин (велика конференц-зала). Куратори секції: Захаренко Г.С., Клименко 3.К., Улейська Л.І., Кушнір А.І.. Секція 1-2. Інтродукція, біоекологічне вивчення і селекція плодових рослин (будівля музею НБС- 
ННЦ). Куратори секції: Смиков А.В., Комар-Темна Л.Д. Секція 1-3. Інтродукція, біоекологічне вивчення і селекція ароматичних рослин (дегустаційна зала ГП ТД Нікітський сад). Куратори секції: Работягов В.Д., Ісіков В.П., Марко Н.В. Секція 2. Вивчення і збереження природної флори та рослинності. Заповідна справа (аудиторія НУБіП). Куратори секції: Корженевський В.В., Маслов I.I., Садогурський С.Ю., Крайнюк Є.С. Секція 3. Фізіолого-біохімічне вивчення рослин в природі і в культурі. Біологічно активні речовини (мала конференц-зала). Куратори секції: Митрофанова I.В., Палій А.С., Ругузова А.І. Секція 4. Садово-паркове будівництво, фітодизайн (велика конференц-зала НБС-ННЦ). Куратори секції: Захаренко Г.С., Клименко 3.К., Улейська Л.І., Кушнір А.І.

На секційних засіданнях були розглянуті всі проблеми, які зараз стоять перед ботанікою, перед вченими ботанічних садів, дендрологічних парків, заповідників, університетів. Але основним лейтмотивом була теза, як не тільки зберегти в наш складний час, а й примножити ботанічні багатства, що накопичені не одним поколінням наших попередників у всьому світі.

Учасники, які представили стендові доповіді у фойє великої конференц-зали, дали вичерпні пояснення та відповіли на запитання. 7 червня були підведені підсумки та урочисте закриття конференції. Важливі питання розвитку ботанічних садів, збереження колекцій та багато інших проблем продовжували жваво обговорювати в колі друзів у неформальній обстановці під час проведення заходу «Ботанічний чай». Для учасників конференції 6 і 8 червня були проведені цікаві екскурсії з ознайомлення 3 рослинним світом та природою Нікітського ботанічного саду і південного берега Криму.

До 200-річного ювілею у видавництві «Н. Оріанда» (Сімферополь, 2011) вийшла 3 друку прекрасно оформлена, чудова книга «Никитский ботанический сад. История и судьбы». Автор книги - І.В.Крюкова, кандидат біологічних наук, ботанік-систематик, більше 30 років працювала науковим співробітником Нікітського ботанічного саду, живе в Нікітському саду більше 50 років. Епіграф до книги звучить так: «Посвящается людям Никитского сада, всем, кто любил его и трудился здесь на благо своей страны», а девізом I.В.Крюкова взяла слова: «Per scientium ad vitam - Через науку в жизнь» (цей девіз ми використали в назві нашої статті, оскільки ці слова відображають сутність діяльності ботанічних закладів, вчених-ботаніків та інших подвижників науки). Якісний текст (понад 400 с.) читається з великим інтересом, на одному диханні. Книга, розміром трохи більше формату А4, насичена величезною кількістю чорно-білих світлин історичного плану та прекрасних кольорових фотографій, що відображають сучасність Нікітського ботанічного саду, в кожній з яких відчувається великий талант та професіоналізм фотохудожника, автора світлин - науковця Нікітського ботанічного саду, доктора біологічних наук, професора Ісікова В.П.

Треба відзначити, що і ювілей, і конференція, i дана книга заставляють задуматися кожного з нас, що треба зробити нині, аби перлина півдня України Нікітський ботанічний сад, один 3 найкрасивіших в Європі та один 3 найдавніших ботанічних садів України, залишався таким на віки. 